AperTO - Archivio Istituzionale Open Access dell'Università di Torino

Design and synthesis of symmetrical pentamethine cyanine dyes as NIR photosensitizers for PDT

This is a pre print version of the following article:

Original Citation:

Availability:

This version is available http://hdl.handle.net/2318/1695380

since 2019-03-25T10:12:54Z

Published version:

DOI:10.1016/j.dyepig.2018.09.009

Terms of use:

Open Access

Anyone can freely access the full text of works made available as "Open Access". Works made available under a Creative Commons license can be used according to the terms and conditions of said license. Use of all other works requires consent of the right holder (author or publisher) if not exempted from copyright protection by the applicable law. 


\title{
Design and synthesis of symmetrical pentamethine cyanine dyes as NIR photosensitizers for PDT
}

\author{
Betty Ciubini ${ }^{\mathrm{a}}$, Sonja Visentin ${ }^{\mathrm{b}}$, Loredana Serpe ${ }^{\mathrm{c}}$, Roberto Canaparo ${ }^{\mathrm{c}}$, Andrea Fin ${ }^{\mathrm{d}}$ and Nadia \\ Barbero $^{\mathrm{a},{ }^{*}}$
}

\begin{abstract}
aDepartment of Chemistry and NIS Interdepartmental Centre, University of Torino, via Pietro Giuria 7, 10125 Torino, Italy. ${ }^{b}$ Molecular Biotechnology and Health Sciences Department, University of Torino, via Quarello 15, 10135 Torino, Italy.

'Department of Drug Science and Technology, University of Torino, via Pietro Giuria 13, 10125 Torino, Italy.

dDepartment of Chemistry and Biochemistry, University of California, San Diego, La Jolla, California 92093-0358, United States Corresponding author. E-mail address: nadia.barbero@unito.it (N. Barbero).
\end{abstract}

\section{Keywords}

Cyanine dyes, Near Infra-Red (NIR), photosensitizers, photodynamic therapy (PDT).

\begin{abstract}
Herein, we report the synthesis and spectroscopic characterization of novel Near Infra-Red (NIR) pentamethine cyanine dyes, as potential photosensitizers for Photodynamic Therapy (PDT) characterized by a strong absorption in the tissue transparency window (600-800 $\mathrm{nm})$. The heteroaromatic benzoindolenine ring of various symmetrical cyanine dyes has been differently functionalized and quaternarized as a result of a structure-activity study and to determine the substituent effect on the cellular uptake, ROS production and photodynamic activity. These probes present low cytotoxicity in dark, but promote phototoxic effect, upon irradiation, in human fibrosarcoma cell line (HT-1080) with interesting and unexpected structure to property activity.
\end{abstract}

\section{Introduction}

NIR dyes had a significant development in bioanalytical or biologically related applications in recent years with a particular focus on in vivo fluorescence imaging due to the low self-fluorescence of the biological molecules in the NIR region of the electromagnetic spectrum. [1,2] NIR polymethine dyes, such as pentamethine and heptamethine cyanines and squaraines, are well suited for this purpose and have been extensively studied for these applications.[3-7] The same strengths that have promoted their development as NIR probes, make these dyes potential candidates as photosensitizers in photodynamic therapy (PDT).[8-11] PDT is a minimally invasive approach exploiting the biological consequences of localized oxidative damage generated by photodynamic processes.[12] Every initial photodynamic process is characterized by the presence of a light-activated drug called photosensitizer (PS), light and oxygen. The PS is excited by a non-thermal light (i.e. LED) at the appropriate excitation wavelength, upon a certain time (drug-to-light interval, DLI) from the administration to the patient. The deactivation of the PS excited state (PS*) occurs mainly by two photochemical processes of relevance in PDT: photoelectric electron transfer or energy transfer from PS* to another molecule like molecular oxygen, 
generating reactive oxygen species (ROS) such a singlet oxygen ${ }^{1} \mathrm{O}_{2} \cdot[13-15]$ An appropriate choice of the PS is of great importance to maximize the treatment effectiveness by high ROS production.

Among the proposed PS,[16,17] polymethine and cyanine dyes, show the desired characteristics of PDT-active photosensitizer.[18] In particular, the easiness in designing NIR molecules provides cyanines with absorption in the phototherapeutic window $(600-850 \mathrm{~nm})$. Several in vivo imaging and PDT studies using heptamethine cyanine and squaraine dyes have been previously reported.[8,19-21] Unsubstituted indolenine- and benzoindolenine-based heptamethinic cyanines have been reported to preferentially accumulate in tumor tissues[3,22]. This interesting observation prompted us to further explore the biological properties of substituted benzoindolenine ring derivatives. In regards to the substituent nature, two to six carbon length side alkyl chains has been reported to optimize the internalization and retention processes in cell.[3,23] The heavy atom effect is usually addressed by insertion, along the molecular scaffold, of bromine atoms which promotes the intersystem conversion in the excited triplet state of the dye increasing the ROS generation. Similar effect was recently described also for squaraine-based PSs.[8,20]

In the present work we investigated the photodynamic potential of a new series of NIR dyes. A new series of NIR symmetrical cyanine dyes, based on a benzoindoleninic ring (Fig. 1), was synthetized and photophysically characterized before being in vitro tested for the evaluation of their cytotoxicity and photo-toxicity.

The heteroaromatic benzoindolenine ring of various symmetrical cyanine dyes has been differently substituted and quaternarized to implement a structure-activity study and to determine the substitutions influence on the cellular uptake, ROS production and photodynamic activity.

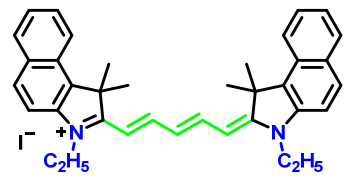

5

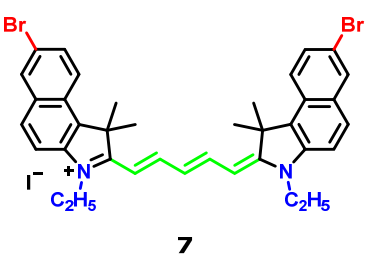

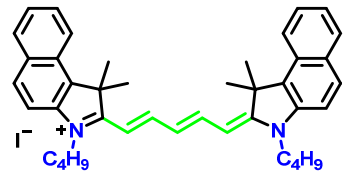

6

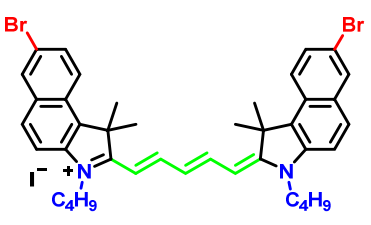

8

Figure 1. Structures of the synthesized symmetrical cyanine dyes.

\section{Experimental details}

\subsection{Materials and techniques}

All the chemicals were purchased from Sigma Aldrich, Fluka, Merck or Riedel de Haen and were used without any further purification.

All microwave reactions were performed in single-mode Biotage Initiator 2.5. TLC were performed on silica gel 60 F254 plates. ESI-MS spectra were recorded using a LCQ Thermo Advantage Max 
spectrometer, with electrospray interface and ion trap as mass analyzer. The flow injection effluent was delivered into the ion source using nitrogen as sheath and auxiliary gas. ${ }^{1} \mathrm{H}$ NMR $(200 \mathrm{MHz})$ and ${ }^{13} \mathrm{C}$ NMR (50 MHz) spectra were recorded on a Bruker Avance $200 \mathrm{NMR}$ in $\mathrm{CDCl}_{3}$ or DMSO-d 6 .

\subsection{Procedure for the preparation of compounds 1-4}

\subsection{1. (6-bromonaphthalen-2-yl)hydrazine (1)}

6-bromonaphthalen-2-ol $(21.15 \mathrm{~g}, 0.95 \mathrm{~mol})$ is cooled down to $0^{\circ} \mathrm{C}$ in a three-neck flask before hydrazine hydrate $(55.18 \mathrm{ml}, 1.14 \mathrm{~mol})$ is added drop by drop. The suspension is warmed up to $60-80^{\circ} \mathrm{C}$ to obtain a clear yellow solution and the reaction is run at $125^{\circ} \mathrm{C}$ for $24 \mathrm{~h}$. After $24 \mathrm{~h}$, the dark orange reaction mixture is cooled down to $60^{\circ} \mathrm{C}$ (below this temperature an undesired phase separation takes place). The hot solution is then poured drop by drop in n-propanol. The suspended solid is filtered and washed with n-propanol to provide (6-bromonaphthalen-2-yl)hydrazine (1) as a white/yellow solid (3.77 g, 16\% yield).

\subsubsection{7-bromo-1,1,2-trimethyl-1H-benzo[e]indole (2b)}

(6-bromonaphthalen-2-yl)hydrazine (1) (3.23 g, $13.64 \mathrm{mmol}), 3$-methylbutan-2-one (4.38 ml, 40.92 $\mathrm{mmol})$ and glacial acetic acid $(15 \mathrm{ml})$ are introduced in a microwave reaction vial, sealed with a crimp cap and heated in the microwave system at $160^{\circ} \mathrm{C}$ for $10 \mathrm{~min}$. The brown solution is left to cool down and the acetic acid is removed under vacuum. The oily residue is partitioned between diethyl ether (50 $\mathrm{ml})$ and water $(150 \mathrm{ml})$. The aqueous phase is washed three times with petroleum ether $(3 \times 50 \mathrm{ml})$. The combined organic solutions are dried and evaporated under vacuum to afford 7-bromo-1,1,2-trimethyl$1 \mathrm{H}$-benzo[e]indole $\mathbf{2 b}(3.56 \mathrm{~g}$, yield $=90 \%)$ as a brown orange oil.

${ }^{1} \mathrm{H}$ NMR (200MHz, CDCl 3$), \delta: 8.14(\mathrm{t}, \mathrm{J}=4.3 \mathrm{~Hz}, 1 \mathrm{H}), 7.85(\mathrm{dt}, \mathrm{J}=14.9,6.6 \mathrm{~Hz}, 3 \mathrm{H}), 7.64(\mathrm{dd}, \mathrm{J}=$ 9.0, $2.0 \mathrm{~Hz}, 1 \mathrm{H}), 2.49$ (s, 3H), 1.57 (s, 6H).

${ }^{13} \mathrm{C} \mathrm{NMR}\left(50 \mathrm{MHz}, \mathrm{CDCl}_{3}\right), \delta: 189.46,150.56,138.41,132.88,131.03,129.12,127.47,126.56,123.56$, $120.46,117.70,76.52,75.89,54.81,22.21$.

MS (ESI) $[\mathrm{M}+\mathrm{H}]^{+} 288.10$

\subsection{3. $N-((1 E, 2 E)-3-($ phenylamino) allylidene)benzenaminium chloride (3)}

Compound 3 was prepared as previously described.[24]

${ }^{1} \mathrm{H}$ NMR (200MHz, DMSO-d 6 ), $\delta: 12.35$ (s, 2H), 8.76 (d, J = $\left.11.3 \mathrm{~Hz}, 2 \mathrm{H}\right), 7.57$ - 7.15 (m, 10H), 6.34 $(\mathrm{t}, \mathrm{J}=11.4 \mathrm{~Hz}, 1 \mathrm{H})$.

\subsubsection{Synthesis of intermediates (4a) and (4b)}

The intermediate 3-ethyl-1,1,2-trimethyl-1H-benzo[e]indol-3-ium iodide (4a) and 3-butyl-1,1,2trimethyl-1H-benzo[e]indol-3-ium iodide (4b) were prepared as previously described, starting from commercially available $\mathbf{2 a}$.[25] 
2.2.4.1. Synthesis of 3-ethyl-1,1,2-trimethyl-1H-benzo[e]indol-3-ium iodide (4a)

1H NMR (200 MHz, DMSO) $\delta 8.50-8.02(\mathrm{~m}, 8 \mathrm{H}), 7.90-7.60$ (m, 4H), 4.61 (q, J = 7.1 Hz, 4H), 2.93 (s, 5H), $1.75(\mathrm{~s}, 11 \mathrm{H}), 1.49$ (t, J = 7.2 Hz, 6H).

\subsubsection{3-butyl-1,1,2-trimethyl-1H-benzo[e]indol-3-ium iodide (4b)}

MS (ESI) $[\mathrm{M}-\mathrm{I}]^{+} 266.16$

${ }^{1} \mathrm{H}$ NMR (200MHz, DMSO-d6), $\delta: 8.28(\mathrm{dt}, \mathrm{J}=21.6,8.6 \mathrm{~Hz}, 4 \mathrm{H}), 7.86-7.68$ (m, 2H), 4.59 (t, J = 7.5 $\mathrm{Hz}, 2 \mathrm{H}), 2.91$ (d, J = 17.5 Hz, 3H), $2.04-1.80$ (m, 2H), $1.77(\mathrm{~s}, 6 \mathrm{H}), 1.48$ (dd, J = 15.8, 7.3 Hz, 2H), $0.97(\mathrm{t}, \mathrm{J}=6.0 \mathrm{~Hz}, 3 \mathrm{H})$.

\subsection{General quaternization synthesis of bromobenzoindolenine}

7-bromo-1,1,2-trimethyl-1H-benzo[e]indole (2b), iodoalkane (4 equivalents), and acetonitrile were introduced in a reaction vial, sealed with a crimp cap and heated in microwave system at $155^{\circ} \mathrm{C}$ for 45 min. The reaction mixture was then poured in diethyl ether $(200 \mathrm{ml})$ to precipitate a brown/green solid which was washed with diethyl ether and filtered.

\subsubsection{7-bromo-3-ethyl-1,1,2-trimethyl-1H-benzo[e]indol-3-ium iodide (4c)}

7-bromo-1,1,2-trimethyl-1H-benzo[e]indole (2) (1 g, 3,48 mmol), iodoethane (1,94 $\mathrm{ml}, 13,9 \mathrm{mmol})$ and anhydrous acetonitrile $(15 \mathrm{ml})$.

$1.19 \mathrm{~g}$, yield $=78 \%$.

${ }^{1} \mathrm{H}$ NMR (200MHz, DMSO-d 6 ), $\delta: 8,54(\mathrm{~d}, J=2,1 \mathrm{~Hz}, 1 \mathrm{H}), 8,29$ (dt, $\left.J=16,4,9,0 \mathrm{~Hz}, 3 \mathrm{H}\right), 7,88$ (dd, $J$ $=9,0,1,9 \mathrm{~Hz}, 1 \mathrm{H}), 4,60$ (q, $J=7,0 \mathrm{~Hz}, 2 \mathrm{H}), 2,89$ (s, 3H), 1,74 (s, 6H), 1,49 (t, $J=7,3 \mathrm{~Hz}, 3 \mathrm{H})$.

${ }^{13} \mathrm{C}$ NMR (50MHz, DMSO-d 6 ), $\delta: 196.70,138.93,134.51,131.82,131.52,130.26,126.08,125.95$, $120.78,114.82,55.78,43.70,21.71,14.00,13.10$.

\subsubsection{7-bromo-3-butyl-1,1,2-trimethyl-1H-benzo[e]indol-3-ium iodide (4d)}

7-bromo-1,1,2-trimethyl-1H-benzo[e]indole (2) (1 g, 3,48 mmol), iodobutane (1,58 ml, 13,9 mmol) and anhydrous acetonitrile $(15 \mathrm{ml})$.

$1.05 \mathrm{~g}$, yield $=64 \%$.

${ }^{1} \mathrm{H}$ NMR (200MHz, DMSO-d 6 ), $\delta: 8,53(\mathrm{~d}, J=1,9 \mathrm{~Hz}, 1 \mathrm{H}), 8,28(\mathrm{dt}, J=15,4,9,0 \mathrm{~Hz}, 3 \mathrm{H}), 7,87$ (dd, $J$ $=9,0,2,0 \mathrm{~Hz}, 1 \mathrm{H}), 4,56(\mathrm{t}, J=7,7 \mathrm{~Hz}, 2 \mathrm{H}), 2,93(\mathrm{~s}, 3 \mathrm{H}), 1,98-1,77(\mathrm{~m}, 2 \mathrm{H}), 1,74(\mathrm{~s}, 6 \mathrm{H}), 1,43$ (dt, $J$ $=14,7,7,4 \mathrm{~Hz}, 2 \mathrm{H}), 0,94(\mathrm{t}, J=7,3 \mathrm{~Hz}, 3 \mathrm{H})$.

${ }^{13} \mathrm{C}$ NMR (50MHz, DMSO-d 6 ), $\delta: 197.02,139.22,137.54,134.52,131.83,131.54,130.23,126.04$, $125.98,120.82,114.98,55.81,48.06,29.71,21.85,19.59,14.19,13.90$.

\subsection{General synthesis of symmetrical cyanines}

Compounds 4a-d (2 mol), N-((1E,2E)-3-(phenylamino)allylidene)benzenaminium chloride (3) (1 mol), anhydrous sodium acetate $(3 \mathrm{~mol})$ and acetic anhydride were introduced in a microwave vial and heated at $130^{\circ} \mathrm{C}$ for $10-20 \mathrm{~min}$. The reaction mixture was poured in diethyl ether to precipitate a blue solid, 
which was washed with diethyl ether and filtered. The blue solid was dissolved in DCM leaving unreacted sodium acetate crystals on the filter funnel. The filtrate was evaporated under vacuum to obtain the cyanine dyes as a blue powder.

\subsubsection{Dye 5}

3-ethyl-1,1,2-trimethyl-1H-benzo[e]indol-3-ium iodide (4a) (500 mg, $1.37 \mathrm{mmol}), \mathrm{N}-((1 \mathrm{E}, 2 \mathrm{E})-3-$ (phenylamino)allylidene)benzenaminium chloride (3) (177 $\mathrm{mg}, 0.68 \mathrm{mmol})$, anhydrous sodium acetate (169 mg, $2.05 \mathrm{mmol})$ and acetic anhydride $(15 \mathrm{ml})$ were introduced in a microwave vial and heated at $130^{\circ} \mathrm{C}$ for $20 \mathrm{~min} .5$ as a blue powder $(375 \mathrm{mg}$, yield $=86 \%$ ).

MS (ESI) $[\mathrm{M}-\mathrm{I}]^{+} 511.28$.

${ }^{1} \mathrm{H}$ NMR (200MHz, DMSO-d 6 ), $\delta: 8.46$ (t, J = 13.1 Hz, 2H), $8.26(\mathrm{~d}, \mathrm{~J}=8.3 \mathrm{~Hz}, 2 \mathrm{H}), 8.07$ (dd, J = 8.2, $5.4 \mathrm{~Hz}, 4 \mathrm{H}), 7.70(\mathrm{dd}, \mathrm{J}=16.4,8.1 \mathrm{~Hz}, 4 \mathrm{H}), 7.57-7.44(\mathrm{~m}, 2 \mathrm{H}), 6.63(\mathrm{t}, \mathrm{J}=12.2 \mathrm{~Hz}, 1 \mathrm{H}), 6.37(\mathrm{~d}, \mathrm{~J}=$ $13.9 \mathrm{~Hz}, 2 \mathrm{H}), 4.28$ (d, J = 7.0 Hz, 4H), 1.93 (d, J = 10.8 Hz, 12H), 1.33 (t, J = 7.0 Hz, 6H).

${ }^{13} \mathrm{C}$ NMR (50MHz, DMSO-d $\left.\mathrm{d}_{6}\right) \delta: 173.48,153.27,139.55,133.50,131.55,130.64,130.21,128.00$, $127.89,125.78,125.03,122.38,111.66,102.79,50.99,26.95,12.73$.

\subsubsection{Dye 6}

3-butyl-1,1,2-trimethyl-1H-benzo[e]indol-3-ium iodide (4b) (1 g, 2.54 mmol), N-((1E,2E)-3(phenylamino)allylidene)benzenaminium chloride (3) (329 mg, $1.27 \mathrm{mmol}$ ), anhydrous sodium acetate (313 $\mathrm{mg}, 3.81 \mathrm{mmol})$ and acetic anhydride $(15 \mathrm{ml})$ were introduced in a microwave vial and heated at $130^{\circ} \mathrm{C}$ for $20 \mathrm{~min} .6$ as a blue-violet powder $(694 \mathrm{mg}$, yield $=79 \%)$.

MS (ESI) $[\mathrm{M}-\mathrm{I}]^{+} 567.52$.

${ }^{1} \mathrm{H}$ NMR (200MHz, DMSO-d 6 ), $\delta: 8.47$ (t, $\left.J=13.1 \mathrm{~Hz}, 2 \mathrm{H}\right), 8.26(\mathrm{~d}, J=8.8 \mathrm{~Hz}, 2 \mathrm{H}), 8.07$ (dd, $J=8.2$, $4.0 \mathrm{~Hz}, 4 \mathrm{H}), 7.71(\mathrm{dd}, J=17.2,8.1 \mathrm{~Hz}, 4 \mathrm{H}), 7.57-7.46(\mathrm{~m}, 2 \mathrm{H}), 6.66(\mathrm{t}, J=12.4 \mathrm{~Hz}, 1 \mathrm{H}), 6.38(\mathrm{~d}, J$ $=13.6 \mathrm{~Hz}, 2 \mathrm{H}), 4.24(\mathrm{t}, J=7.5 \mathrm{~Hz}, 4 \mathrm{H}), 1.94(\mathrm{~d}, J=12.1 \mathrm{~Hz}, 12 \mathrm{H}), 1.82-1.64(\mathrm{~m}, 4 \mathrm{H}), 1.53-1.33$ $(\mathrm{m}, 4 \mathrm{H}), 0.95(\mathrm{t}, J=7.2 \mathrm{~Hz}, 6 \mathrm{H})$.

${ }^{13} \mathrm{C}$ NMR (50MHz, DMSO-d 6 ) $\delta: 173.89,153.09,139.98,133.40,131.53,130.57,130.19,128.01$, $127.85,125.05,122.42,111.90,103.24,50.96,43.60,29.66,27.06,19.73,14.06$.

\subsubsection{Dye 7}

7-bromo-3-ethyl-1,1,2-trimethyl-1H-benzo[e]indol-3-ium iodide (4c) $(500 \mathrm{mg}, 1.13 \mathrm{mmol}), \mathrm{N}-$ ((1E,2E)-3-(phenylamino)allylidene)benzenaminium chloride (3) (146 mg, $0.56 \mathrm{mmol}$ ), anhydrous sodium acetate $(139 \mathrm{mg}, 1.69 \mathrm{mmol})$ and acetic anhydride $(15 \mathrm{ml})$ were introduced in a microwave vial and heated at $130^{\circ} \mathrm{C}$ for $10 \mathrm{~min} .7$ as a blue powder ( $353 \mathrm{mg}$, yield $=79 \%$ ).

MS (ESI) [M-I] 669.21

${ }^{1} \mathrm{H}$ NMR (200MHz DMSO-d $)$ ), $\delta: ~ 8.55-8.34$ (m, 4H), 8.22 (d, $\left.J=9.1 \mathrm{~Hz}, 2 \mathrm{H}\right), 8.09$ (d, $J=9.0 \mathrm{~Hz}$, 2H), 7.77 (dd, $J=14.1,5.3 \mathrm{~Hz}, 4 \mathrm{H}), 6.64$ (t, $J=12.4 \mathrm{~Hz}, 1 \mathrm{H}), 6.38(\mathrm{~d}, J=14.0 \mathrm{~Hz}, 2 \mathrm{H}), 4.28$ (t, $J=$ $6.8 \mathrm{~Hz}, 4 \mathrm{H}), 1.92(\mathrm{~s}, 12 \mathrm{H}), 1.32(\mathrm{t}, J=6.8 \mathrm{~Hz}, 6 \mathrm{H})$. 
${ }^{13} \mathrm{C}$ NMR (50MHz, DMSO-d 6 ) $\delta: 172.75,152.82,139.45,133.12,132.12,131.25,130.16,129.32$, $125.69(\mathrm{~d}, \mathrm{~J}=6.5 \mathrm{~Hz}), 124.03,117.18,112.30,102.50,50.30,26.30,12.06$.

\subsubsection{Dye 8}

7-bromo-3-butyl-1,1,2-trimethyl-1H-benzo[e]indol-3-ium iodide (4d) (500 mg, $1.06 \mathrm{mmol}$ ), N((1E,2E)-3-(phenylamino)allylidene)benzenaminium chloride (3) $(137 \mathrm{mg}, 0.53 \mathrm{mmol})$, anhydrous sodium acetate $(130 \mathrm{mg}, 1.59 \mathrm{mmol})$ and acetic anhydride $(15 \mathrm{ml})$ were introduced in a microwave vial and heated at $130^{\circ} \mathrm{C}$ for $10 \mathrm{~min} .8$ as a blue powder $(369 \mathrm{mg}$, yield $=82 \%)$.

MS (ESI) $[\mathrm{M}-\mathrm{I}]^{+} 725.25$

${ }^{1} \mathrm{H}$ NMR (200MHz, DMSO-d $)$ ), $\delta: 8.56-8.32(\mathrm{~m}, 4 \mathrm{H}), 8.23(\mathrm{~d}, J=9.1 \mathrm{~Hz}, 2 \mathrm{H}), 8.08$ (d, $J=8.9 \mathrm{~Hz}$, 2H), 7.78 (dd, $J=14.4,5.5 \mathrm{~Hz}, 4 \mathrm{H}), 6.67$ (t, $J=12.4 \mathrm{~Hz}, 1 \mathrm{H}), 6.39$ (d, $J=13.8 \mathrm{~Hz}, 2 \mathrm{H}), 4.23$ (t, 4H), $1.72(\mathrm{~s}, 4 \mathrm{H}), 1.42(\mathrm{dd}, J=15.3,7.5 \mathrm{~Hz}, 4 \mathrm{H}), 0.94(\mathrm{t}, J=7.3 \mathrm{~Hz}, 6 \mathrm{H})$.

${ }^{13} \mathrm{C}$ NMR (50MHz, DMSO-d $\left.\mathrm{d}_{6}\right) \delta: 173.99,153.47,140.66,133.85,132.91,132.05,130.99,130.08$, $126.53,124.87,118.04,113.32,103.73,51.10,43.92,27.25,19.91,14.25$.

\subsection{Spectroscopic characterization of the symmetrical cyanines}

\subsubsection{UV-Vis spectroscopy}

UV-Vis spectra were recorded on a Shimadzu UV-1700 Pharma Spec using different solvents in order to investigate the solvatochromic behavior of the symmetrical cyanines. A stock solution $(0.7 \mathrm{mM})$ in absolute ethanol (EtOH) was prepared and diluted solutions in acetone, dimethylformamide (DMF), methanol, acetonitrile, tetrahydrofuran (THF), dichloromethane (DCM) and DMSO were analyzed.

\subsubsection{Determination of Molar Extinction Coefficient}

A concentrated solution per each dye was prepared by weighting the dyes (5-7 $\mathrm{mg})$ and dissolving them in $10 \mathrm{ml}$ of absolute ethanol (EtOH). Three diluted solution $(25 \mathrm{ml})$ of EtOH were prepared by taking aliquots $(0.2,0.1$ and $0.05 \mathrm{ml})$ of the stock solution. The diluted solutions were measured by UV-Vis spectroscopy (Shimadzu UV-1700) using quartz cuvettes (1 cm pathway length). The absorbance intensities of each solution at the $\lambda_{\max }$ were plotted versus the sample concentration. A linear fit was applied to determine the molar extinction coefficient $(\varepsilon)$ as the slope of the line. The analysis was performed in duplicate. The obtained data were considered acceptable when the difference between the determined $\log \varepsilon$ was less or equal to 0.02 in respect to their average. Otherwise new concentrated dye stock solution in absolute EtOH was prepared and the protocol repeated.

\subsubsection{Fluorescence spectroscopy}

Fluorescence measurements were recorded using a HORIBA Jobin Yvon Fluorolog 2. Diluted solutions with absorbance around or lower of 0.1 units were used to avoid the presence of aggregates. Fluorescence lifetimes were obtained using a proper NanoLED source $(636 \mathrm{~nm})$ and a photon counting detector (TBX04). The data were fitted to a single exponential function giving the lifetime. The 
goodness of the fit was assessed by the chi-squared value of less than 1.05 and a residual trace that was symmetric about the zero axes. Fluorescence quantum yields were determined using the same instrument with Quanta- $\varphi$ integrating sphere and De Mello method. The final result is an average of three independent measurements.

\subsection{Biological assays}

\subsubsection{Cell line and cytotoxicity assay}

The human fibrosarcoma cell line, HT-1080, was obtained from the American Type Culture Collection (ATCC, Rockville, MD, USA). HT-1080 cells were grown as a monolayer culture in Eagle's Minimum Essential Medium (EMEM, Sigma-Aldrich, Milano, Italy) supplemented with 10\% heat-inactivated fetal calf serum, $2 \mathrm{mM}$ L-glutamine, $100 \mathrm{UI} / \mathrm{mL}$ penicillin and $100 \mu \mathrm{g} / \mathrm{mL}$ streptomycin (SigmaAldrich), at $+37^{\circ} \mathrm{C}$ in a humidified atmosphere of $5 \% \mathrm{CO}_{2}$ in air. HT-1080 cells in the exponential growth phase were detached using $0.05 \%$ trypsin- $0.02 \%$ EDTA solution (Sigma-Aldrich), resuspended in culture medium and seeded at the appropriate cell concentration for cell culture experiments.

The WST-1 cell proliferation assay was used to evaluate the cytotoxic effect on HT-1080 cells of cyanine dyes, i.e., 5, 7, 6 and $\mathbf{8}$, to select the concentration suitable for the in vitro PDT. Specifically, $1.5 \times 10^{3}$ cells were seeded in $100 \mu \mathrm{L}$ of culture medium in replicates $(\mathrm{n}=8)$ in 96 -well culture plates (TPP, Trasadingen, Switzerland), and after $24 \mathrm{~h}$ of cell growth the medium was removed, and the cells incubated with experimental media of differing cyanine dyes' concentrations (1, 10, 50 and $100 \mathrm{nM})$. The WST-1 reagent (Sigma-Aldrich, $10 \mu \mathrm{L} / 100 \mu \mathrm{L}$ ) was added at 24, 48, and $72 \mathrm{~h}$ and the plates were incubated at $+37^{\circ} \mathrm{C}$ in $5 \% \mathrm{CO}_{2}$ in air for $1.5 \mathrm{~h}$. The well absorbance was measured at 450 and $620 \mathrm{~nm}$ (reference wavelength) in a microplate reader (Asys UV340; Biochrom, Cambridge, UK).

\subsubsection{Flow cytometric analysis}

The cellular uptake of cyanine dyes, i.e., 5, 6, 7 and 8, was evaluated by a flow cytometric analysis (BD Accuri C6, Becton, Dickinson Bioscience, Milano, Italy). Briefly, $1.5 \times 10^{5}$ cells were plated in 6-well culture plates (TPP) and after $24 \mathrm{~h}$ incubated with cyanine dyes at the maximum non-cytotoxic concentration tested $(10 \mathrm{nM})$ for 1, 4 and $24 \mathrm{~h}$. Cells were then detached after each incubation period using a $0.05 \%$ trypsin- $0.02 \%$ EDTA solution (Sigma Aldrich) and re-suspended in $300 \mu \mathrm{L}$ of phosphate buffered solution (PBS, Sigma Aldrich). Cells were then run on the flow cytometer considering 10,000 events at a $640 \mathrm{~nm}$ excitation to measure the intracellular dye.

Reactive oxygen species (ROS) production was evaluated 1, 5, 15, 30, 45, 60 min after the in vitro PDT with the different cyanine dyes carried out as described below. HT-1080 cells were incubated with 10 $\mu \mathrm{M}$ of 2',7'-dichlorofluorescein diacetate (DCFH-DA) (Sigma Aldrich) for $30 \mathrm{~min}, 1 \mathrm{~h}$ after incubation with cyanine dyes, i.e., 5, 6, 7 and 8 at $10 \mathrm{nM}$. After the in vitro PDT, cells were analyzed for ROS production by flow cytometry evaluating 10,000 events at a $488 \mathrm{~nm}$ excitation. ROS production was 
expressed as integrated median fluorescence intensity (iMFI), which is the product of the frequency of ROS-producing cells and the median fluorescence intensity of the cells.

\subsubsection{In vitro photodynamic treatment}

HT-1080 cells in the exponential phase were pre-incubated in the dark for $1 \mathrm{~h}$, the time needed for an efficient internalization, in a culture medium containing cyanine dyes at $10 \mathrm{nM}$, i.e., the maximum noncytotoxic concentration tested. Cells were removed from the flask after incubation using a $0.05 \%$ trypsin- $0.02 \%$ EDTA solution (Sigma Aldrich) and normalized to $1.5 \times 10^{5}$ cells in $1 \mathrm{~mL}$ of PBS in polystyrene tubes (TPP). The light-emitting source was based on a light beam (LB), specifically a red LED with a wavelength of $636 \mathrm{~nm}$ and energy fluency rates adjusted to $15 \mathrm{~mW} / \mathrm{cm}^{2}$. Briefly, cellular suspensions were exposed to the LB for $20 \mathrm{~min}$ in a dark box. After PDT, $1.5 \times 10^{3}$ cells were plated in a 96-well culture plate (TPP) and cell proliferation was evaluated at 24, 48 and $72 \mathrm{~h}$ using the WST-1 cell proliferation reagent $(10 \mu \mathrm{L} / 100 \mu \mathrm{L})$. Cell proliferation data are expressed as a percentage of the absorbance of treated cells $v s$ untreated cells.

\subsubsection{Statistical analysis}

Data are shown as average values of three independent experiments \pm standard deviation. Statistical analyses were performed using Graph-Pad Prism 5.0 software (La Jolla, CA, USA); one-way and twoway analyses of variance and Bonferroni's test were used to calculate the threshold of significance. Statistical significance was set at $p<0.05$. 


\section{Results and discussion}

\subsection{Synthesis}

The synthesis of symmetrical brominated and non-brominated pentamethine cyanine dyes involved the condensation of the quaternary heterocyclic salts, bearing an activated methyl group, with malonodialdehyde derivatives.[24] While 1,1,2-trimethyl-1H-benzo[e]indole (2a) is commercially available, the 7-bromo-1,1,2-trimethyl-1H-benzo[e]indole (2b) was readily obtained exploiting the Fischer indole synthesis by reacting (6-bromonaphthalen-2-yl)hydrazine with 3-methylbutan-2-one in glacial acetic acid, as previously described for the reported bromoindolium iodide[26] and carboxybenzoindolium iodide[27] (see Scheme 1). The subsequent quaternization of the benzoindolenine ring, performed under microwave irradiation[26,27], led to an increased acidity of the methyl group which enabled the cyanine bridge formation (see first step in Scheme 2).

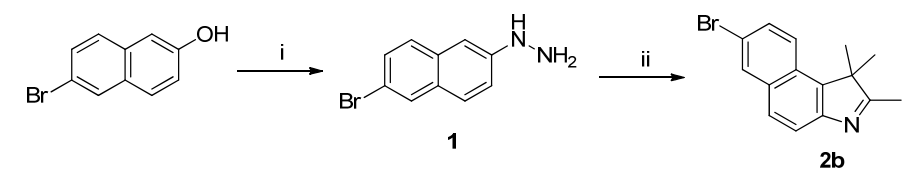

Scheme 1. Synthesis of bromobenzoindolenine. Experimental conditions: (i) hydrazine hydrate, $0^{\circ} \mathrm{C}$; $125^{\circ} \mathrm{C}, 24 \mathrm{~h}$; (ii) 3-methylbutan-2-one, glacial acetic acid, MW, $10 \mathrm{~min}, 160^{\circ} \mathrm{C}$.

The characterization of quaternarized salts of 1,1,2-trimethyl-1H-benzo[e]indole (4a-b) matched the previously reported in literature.[25] All the symmetrical cyanine dyes were synthesized in a one-step reaction under microwave heating following a green method published by Owens et al.[28] by reacting two equivalents of quaternary heterocyclic salts with the malonoaldehyde bis(phenylimine)monohydrochloride (3) in the presence of sodium acetate and acetic anhydride (see Scheme 2). The reaction mixture was finally poured in diethyl ether to precipitate a blue solid, which was washed and filtered. Unreacted sodium acetate crystals were then removed by DCM. Finally, cyanine dyes were obtained in good yields (79-86\%).

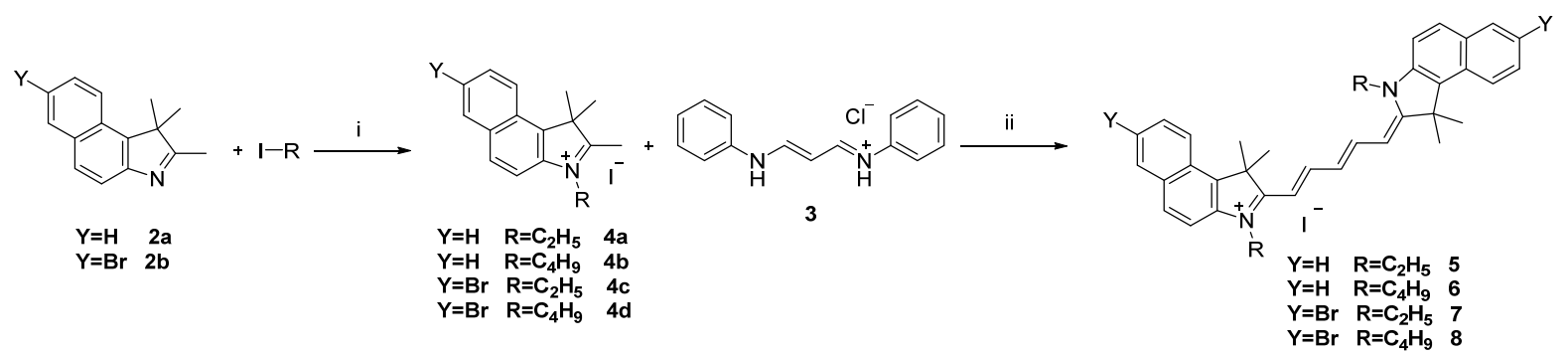

Scheme 2. Synthesis of 5, 6, 7 and $\mathbf{8}$ dyes. Experimental conditions: (i) anhydrous acetonitrile, iodoalkane, $\mathrm{MW}, 45 \mathrm{~min}, 155^{\circ} \mathrm{C}$; (ii) sodium acetate, acetic anhydride, $\mathrm{MW}, 10 / 20 \mathrm{~min}, 130^{\circ} \mathrm{C}$. 


\subsection{Spectroscopic characterization of the symmetrical cyanine dyes}

All compounds show a narrow absorption band in the NIR, perfectly matching the phototherapeutic window, with the hypsochromic shoulder typical for cyanine dyes. The electronic absorption and emission spectra of the compounds, in EtOH, are depicted in Figure 2 while the main photophysical parameters in EtOH and DMSO are reported in Table 1 and 2. Different substituents (i.e., presence or absence of $\mathrm{Br}$ and length of the alkyl chain) on the benzoindolenine ring have no effect on the $\lambda_{\max }$ suggesting that the electronic levels, involved in the $\pi-\pi^{*}$ transition, have similar energies.[29] All the compounds are characterized by an absorption maximum around 680-695 $\mathrm{nm}$ and molar extinction coefficient varying from 160,000 to $225,000 \mathrm{M}^{-1} \mathrm{~cm}^{-1}$.

The solvatochromic effect on the compounds absorption spectra was also investigated as depicted in Figure 3 for dye 5 . As general trend, neither the absorption maxima nor the band shape are affected by the solvent polarity. DCM induces a $15 \mathrm{~nm}$ bathochromic shift in comparison to $\mathrm{MeOH}$ suggesting a more polar ground state in comparison to the excited one. No significant differences were observed in the absorption peak maxima in protic or aprotic solvents. Similar effect was recorded in the emission spectra. Moreover, the low Stokes shift $(20 \mathrm{~nm})$ value indicates that a moderate geometry change occurs from the ground to the excited state.

Fluorescence lifetimes $\left(\tau_{\mathrm{f}}\right)$ show monoexponential decay and are in the ns range. The alkyl chain length on the benzoindolenine ring slightly influences $\tau_{\mathrm{f}}$. A small $\tau_{\mathrm{f}}$ increase is evident with longer chains, both on brominated and non-brominated dyes. The fluorescence quantum yield shows an opposite behaviour varying from 29 to $38 \%$ as expected for cyanine dyes.

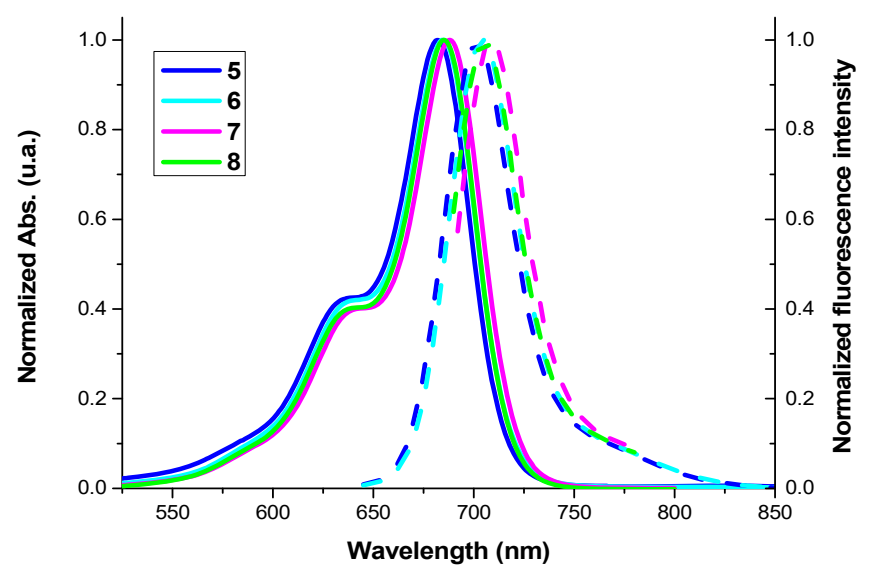

Figure 2. Normalized UV-Vis and fluorescence spectra of the synthesized symmetrical cyanine dyes in absolute ethanol. 


\section{Table 1}

Selected photophysical properties of symmetrical cyanine dyes in absolute ethanol.

\begin{tabular}{ccccc}
\hline Dye & $\begin{array}{c}\lambda_{\text {abs }} \\
(\mathrm{nm})\end{array}$ & $\begin{array}{c}\varepsilon \\
\left(\mathrm{M}^{-1} \mathrm{~cm}^{-1}\right)\end{array}$ & $\begin{array}{c}\lambda_{\mathrm{em}} \\
(\mathrm{nm})\end{array}$ & $\begin{array}{c}\text { Stokes shift } \\
(\mathrm{nm})\end{array}$ \\
\hline $\mathbf{5}$ & 682 & $1.60 \cdot 10^{5}$ & 702 & 20 \\
$\mathbf{6}$ & 684 & $1.88 \cdot 10^{5}$ & 704 & 20 \\
$\mathbf{7}$ & 685 & $2.25 \cdot 10^{5}$ & 705 & 20 \\
$\mathbf{8}$ & 688 & $2.08 \cdot 10^{5}$ & 709 & 21 \\
\hline
\end{tabular}

\section{Table 2}

Fluorescence lifetime and quantum yields of symmetrical cyanine dyes in DMSO.

\begin{tabular}{cccccc}
\hline Dye & $\begin{array}{c}\lambda_{\mathrm{abs}} \\
(\mathrm{nm})\end{array}$ & $\begin{array}{c}\lambda_{\mathrm{em}} \\
(\mathrm{nm})\end{array}$ & $\begin{array}{c}\text { Stokes shift } \\
(\mathrm{nm})\end{array}$ & $\begin{array}{c}\Phi \\
(\%)\end{array}$ & $\begin{array}{c}\tau_{f} \\
(\mathrm{~ns})\end{array}$ \\
\hline $\mathbf{5}$ & 686 & 705 & 19 & 30.2 & 1.31 \\
$\mathbf{6}$ & 689 & 709 & 20 & 29.1 & 1.42 \\
$\mathbf{7}$ & 689 & 709 & 20 & 38.1 & 1.45 \\
$\mathbf{8}$ & 692 & 713 & 19 & 36.5 & 1.57 \\
\hline
\end{tabular}
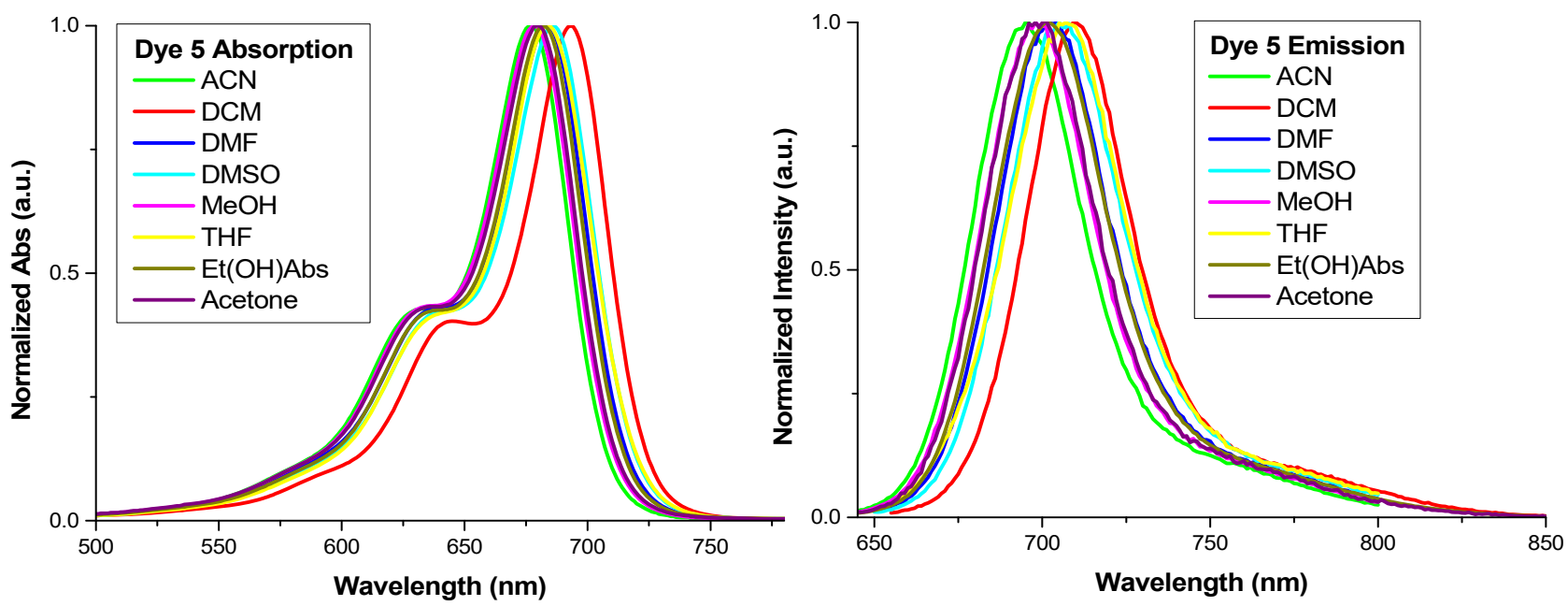

Figure 3. Solvatochromic behavior of dye 5 .

\subsection{In vitro photodynamic activity}

\subsubsection{Effect of cyanine dye-based photodynamic treatment on HT-1080 cell proliferation}

HT-1080 cells were exposed to increasing concentration (1, 10, 50 and $100 \mathrm{nM})$ of each cyanine dye, i.e., $\mathbf{5 , 6}, \mathbf{7}$ and $\mathbf{8}$, to determine the maximum non-cytotoxic concentration suitable for performing the in vitro PDT. A dose-dependent cytotoxicity was observed for all the cyanine dyes (Figure 4). All the 
cyanine dyes induced a decrease of HT-1080 cell proliferation after $48 \mathrm{~h}$ of incubation at the highest concentration of $100 \mathrm{nM}(5 p<0.01 ; 7,6$ and $8 p<0.001)$, while at $50 \mathrm{nM}$ the decrease of cell proliferation was of course more modest ( $5 p<0.01 ; 7$ and $6 p<0.001)$. Interestingly, 6 was the only dye that induced a significant cytotoxicity already after $24 \mathrm{~h}$ of incubation either at $50 \mathrm{nM}(p<0.01)$ and $100 \mathrm{nM}(p<0.001)$. On the other hand, the brominated derivative 8 almost unaffected HT-1080 cell proliferation until $72 \mathrm{~h}$ of incubation at $50 \mathrm{nM}$ and produced a lower decrease of cell proliferation at $100 \mathrm{nM}$ when compared to the other cyanines. Based on these results, the highest non-cytotoxic concentration was $10 \mathrm{nM}$ for all the examined cyanine dyes (Figure 4).

Dye 5

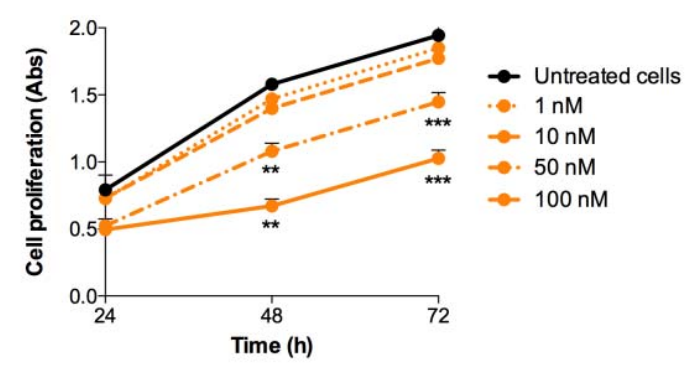

Dye 6

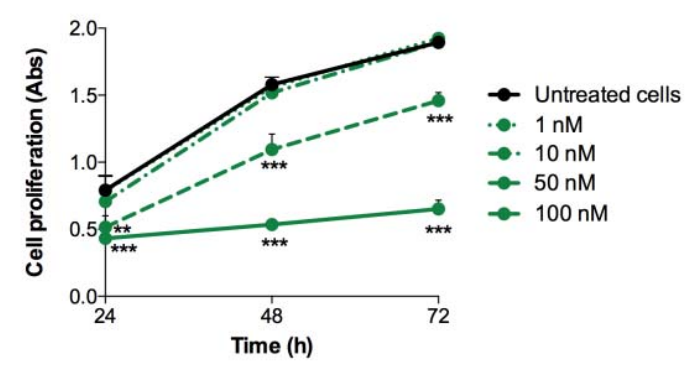

Dye 7

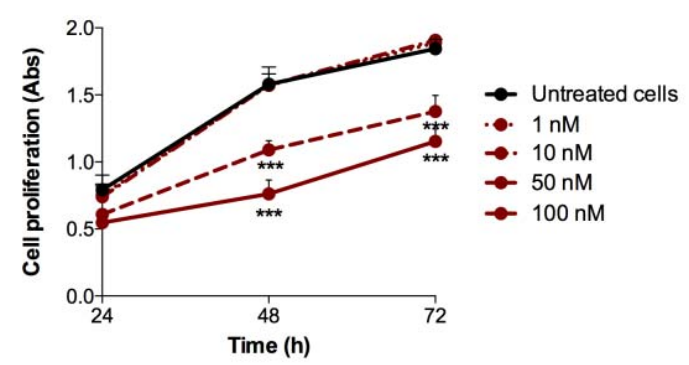

Dye 8

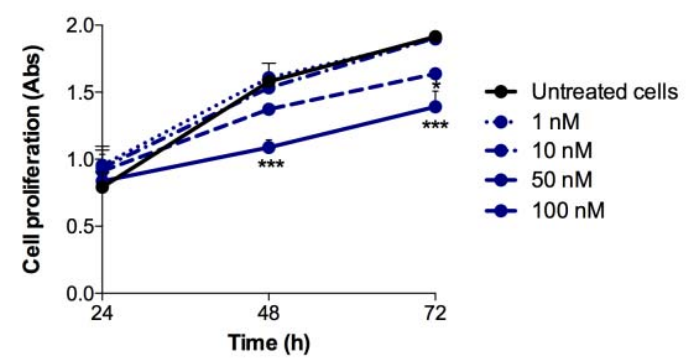

Figure 4. Effects of cyanine dyes on HT-1080 cell proliferation. Cell proliferation, after exposure to increasing concentrations of cyanine dyes $(1,10,50,100 \mathrm{nM})$, was evaluated at 24,48 and $72 \mathrm{~h}$ by WST-1 assay. Statistical significance $v s$ untreated cells: ${ }^{* *} p<0.05,{ }^{* *} p<0.01,{ }^{* * *} p<0.001$.

The HT-1080 cell uptake of cyanine dyes was then evaluated cytofluorimetrically after 1, 4 and $24 \mathrm{~h}$ of incubation of the cells with the minimum non-cytotoxic concentration i.e. $10 \mathrm{nM}$. All the cyanine dyes were efficiently internalized by HT-1080 cells just after $1 \mathrm{~h}$ of incubation (Figure 5), suggesting a rapid and effective cellular uptake which could be related to the lipophilic/cationic structure of these dyes. 


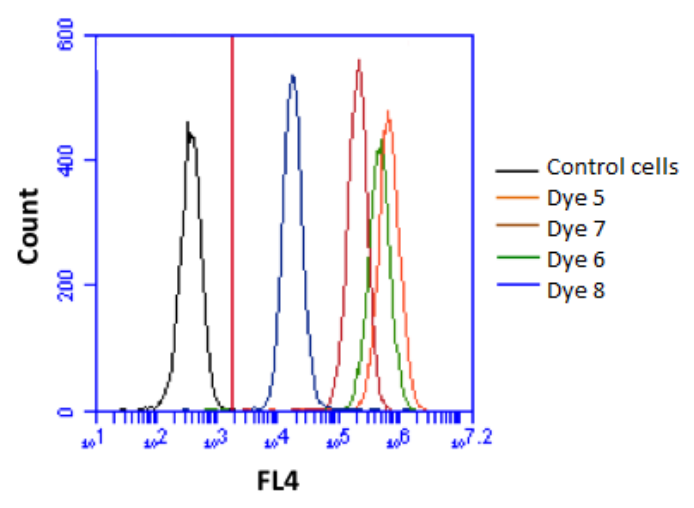

Figure 5. Flow cytometric analysis of cyanine dyes' cell uptake. HT-1080 cells were incubated with cyanine dyes at the same concentration $(10 \mathrm{nM})$ for $1 \mathrm{~h}$. Fluorescent signal was detected using a flow cytometer at $640 \mathrm{~nm}$ excitation (FL4) to measure the cellular cyanine dye fluorescence with respect to untreated cells (control cells).

Once obtained the minimum non-cytotoxic concentration and the specific time for cyanine dyes uptake, the potential photocytotoxicity of each cyanine dye was evaluated by performing an in vitro photodynamic treatment.

The light-induced cytotoxic effect of each cynine dye was observed up to $72 \mathrm{~h}$ after the photodynamic treatment. While HT-1080 cell proliferation was unaffected by control treatments, i.e., exposure to cyanine dye $(10 \mathrm{nM})$ or light beam alone ( $\mathrm{LB}, 15 \mathrm{~mW} / \mathrm{cm}^{2}$ for $\left.20 \mathrm{~min}\right)$, a cytotoxic photodynamic effect was observed with each cyanine dye, becoming more significant at $72 \mathrm{~h}$ after PDT. In comparison to untreated HT-1080 cells, a slight cell proliferation reduction was observed for $5(70.9 \% \pm 18.3 \%$, p < $0.05)$ while stronger reduction was reported with $7(53.6 \% \pm 13.3 \%, p<0.001), 6(49.1 \% \pm 10.2 \%, p$ $<0.001)$ and $8(56.7 \% \pm 10.5 \%, p<0.001) 72 \mathrm{~h}$ after PDT. Surprisingly, a very small difference in the photoactivity behavior was found when comparing $\mathbf{6}$ with the brominated analog 8 . The heavy atom effect on the PDT activity is well-known documented for similar series of indolenine based cyanine[19] and squaraine dyes.[20] This different behaviour could be explained by the relative position of the bromine on the dye structure. The heavy atom effect is remarkable when directly linked to an indolenine ring. In the present work the bromine atom is on a benzoindolenine structure. We speculate that this position could have certain effect on the distance and on the effect on the dye photoactivity. On the other hand, the longer alkyl chains connected to the cyanine structure favour the photoactivity as reported in literature.[23] 


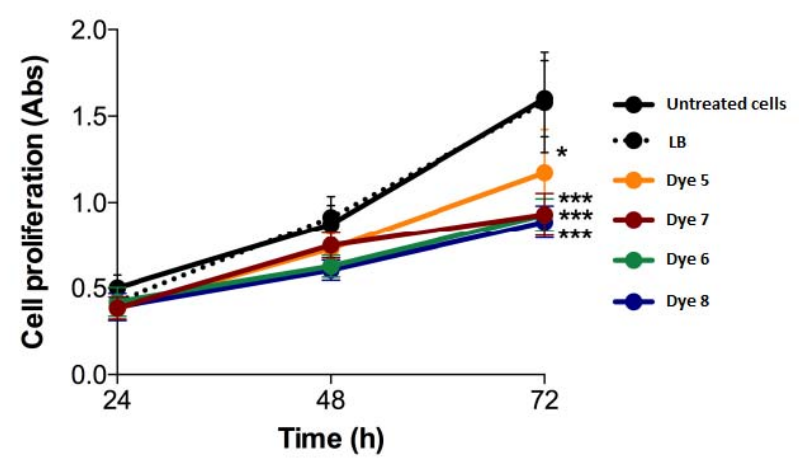

Figure 6. Effect of photodynamic treatment on HT-1080 cell proliferation. Cells were incubated for 1 $\mathrm{h}$ with different cyanine dyes at the same concentration $(10 \mathrm{nM})$ and then exposed to PDT with a light beam (LB, $636 \mathrm{~nm}$ ) at $15 \mathrm{~mW} / \mathrm{cm}^{2}$ for $20 \mathrm{~min}$. Cell proliferation was evaluated after 24,48 and $72 \mathrm{~h}$ by WST-1 assay. Statistically significant difference $v s$ untreated cells: ${ }^{*} p<0.05,{ }^{* * *} p<0.001$.

\subsubsection{Effects of cyanine dye-based photodynamic treatment on reactive oxygen species production}

DCFH-DA (2', 7'-dichlorofluorescin diacetate) was used as ROS probe to evaluate the intracellular ROS generation after PDT by flow cytometry. Highly fluorescent DCF is generated in presence of peroxides and can be excited at $488 \mathrm{~nm}$ where the synthetized cyanine dyes do not absorb light. 5 showed a different ROS generation pattern with respect to other cyanine dyes, maybe in line with its different photodynamic cytotoxic effect. An increased intracellular production of ROS, reaching a maximum 45 minutes after the photodynamic treatment was observed upon irradiation at proper wavelength of 5. On the other hand, 7, 6 and $\mathbf{8}$ showed a rapid increase in ROS production after the photodynamic treatment with a reaching the highest ROS value after 1, 15 and $1 \mathrm{~min}$, respectively. Similar ROS production decrease that reset after $45 \mathrm{~min}$ from the photodynamic treatment was observed for 7 and 8.

It is worth noting that the cyanine dyes which produce higher values of ROS in the shorter time in i.e., 7, 8 and 6, are the more photo-cytotoxic in the in vitro PDT treatment (Figure 6). Finally, it has to be pointed out that the highest ROS production values were obtained by treatment with $\mathbf{5}$ and $\mathbf{7} 45$ and 1 minute after light exposure respectively. 


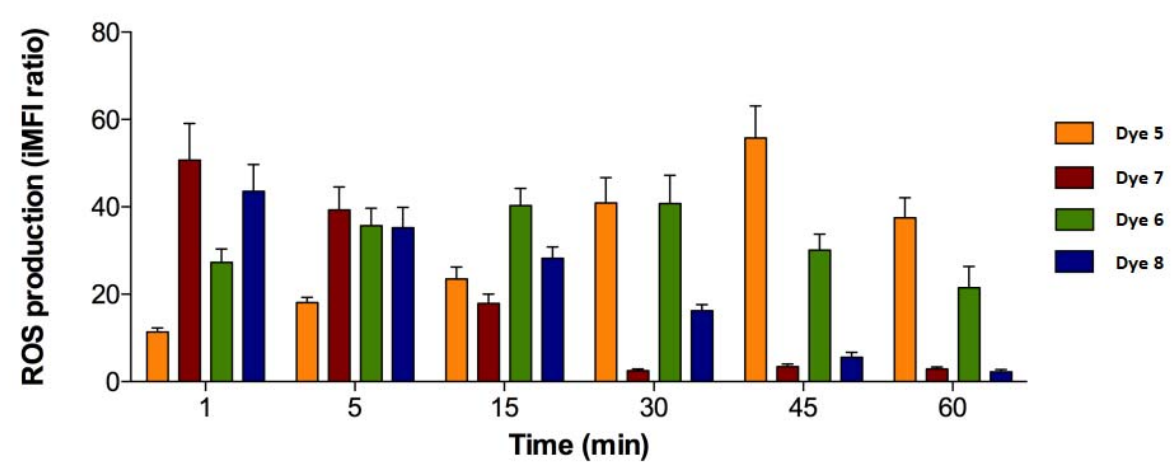

Figure 7. HT-1080 reactive oxygen species (ROS) production after PDT. HT-1080 cells were exposed to PDT with a light beam (LB, $636 \mathrm{~nm}$ ) at $15 \mathrm{~mW} / \mathrm{cm}^{2}$ for $20 \mathrm{~min}$, alone or after cell incubation for $1 \mathrm{~h}$ with cyanine dyes at the same concentration $(10 \mathrm{nM})$. ROS levels were determined according to the dichlorofluorescin-diacetate assay by flow cytometry and expressed as the integrated median fluorescence ratio (iMFI), as described in Materials and Methods.

\section{Conclusions}

We have reported the synthesis of new symmetrical brominated and non-brominated penthametine cyanine dyes varying the alkyl chain lengths which confer different lipophilicity characteristics. The absorption maxima around 680-695 $\mathrm{nm}$ are not affected by the different substituent on the benzoindolenine ring (i.e. length of the alkyl chain). We have demonstrated that, different from other reported photosensitizers, the presence of a heavy atom such bromine has no remarkable influence on the photodynamic effect for this series of probes. All the tested cyanine dyes show a certain phototoxicity which is slightly higher for the brominated-cyanine with longer alkyl chain (four carbons). Moreover, both brominated and non-brominated benzoindolenine-based cyanines were able to produce ROS and were efficiently internalized by HT-1080 cells just after $1 \mathrm{~h}$ of incubation. To our surprise, the presence of bromine on the benzoindolenine ring was depicted by a faster rate of ROS production but has no effect on the photoactivity experiments. This behavior can be explained by the different position of the heavy atom with respect to the other series of polymethine dyes reported in literature. It is worth noting that these molecules are active at very low concentration $(10 \mathrm{nM})$, making them suitable and appealing for in vivo application with the possibility of low dose effectiveness.

\section{Acknowledgements}

Authors acknowledge the financial support from the University of Torino (Ricerca Locale ex-60\%, Bando 2016).

\section{References}

[1] Luo S, Zhang E, Su Y, Cheng T, Shi C. A review of NIR dyes in cancer targeting and imaging. 
Biomaterials 2011;32:7127-38. doi:10.1016/j.biomaterials.2011.06.024.

[2] Fabian J, Nakazumi H, Matsuoka M. Near-Infrared Absorbing Dyes. Chem Rev 1992;92:1197-226. doi:10.1021/cr00014a003.

[3] Zhang C, Liu T, Su Y, Luo S, Zhu Y, Tan X, et al. A near-infrared fluorescent heptamethine indocyanine dye with preferential tumor accumulation for in vivo imaging. Biomaterials 2010;31:6612-7. doi:10.1016/j.biomaterials.2010.05.007.

[4] Pauli J, Vag T, Haag R, Spieles M, Wenzel M, Kaiser WA, et al. An in vitro characterization study of new near infrared dyes for molecular imaging. Eur J Med Chem 2009;44:3496-503. doi:10.1016/j.ejmech.2009.01.019.

[5] Shimi M, Sankar V, Rahim MKA, Nitha PR, Das S, Radhakrishnan K V., et al. Novel glycoconjugated squaraine dyes for selective optical imaging of cancer cells. Chem Commun 2017;53:1-4. doi:10.1039/c6ec10282d.

[6] Bertolino CA, Caputo G, Barolo C, Viscardi G, Coluccia S. Novel heptamethine cyanine dyes with large stoke's shift for biological applications in the near infrared. J Fluoresc 2006;16:221-5. doi:10.1007/s10895-006-0094-8.

[7] Miletto I, Gilardino A, Zamburlin P, Dalmazzo S, Lovisolo D, Caputo G, et al. Highly bright and photostable cyanine dye-doped silica nanoparticles for optical imaging: Photophysical characterization and cell tests. Dye Pigment 2010;84:121-7. doi:10.1016/j.dyepig.2009.07.004.

[8] Avirah RR, Jayaram DT, Adarsh N, Ramaiah D. Squaraine dyes in PDT: from basic design to in vivo demonstration. Org Biomol Chem 2012;10:911. doi:10.1039/c1ob06588b.

[9] Shi C, Wu JB, Pan D. Review on near-infrared heptamethine cyanine dyes as theranostic agents for tumor imaging, targeting, and photodynamic therapy. J Biomed Opt 2016;21:50901. doi:10.1117/1.JBO.21.5.050901.

[10] Barbero N, Visentin S, Viscardi G. The different kinetic behavior of two potential photosensitizers for PDT. J Photochem Photobiol A Chem 2015;299:38-43. doi:10.1016/j.jphotochem.2014.11.002.

[11] Miletto I, Fraccarollo A, Barbero N, Barolo C, Cossi M, Marchese L, et al. Mesoporous silica nanoparticles incorporating squaraine-based photosensitizers: a combined experimental and computational approach. Dalt Trans 2017:15-8. doi:10.1039/C7DT03735J.

[12] Rkein AM, Ozog DM. Photodynamic therapy. Dermatol Clin 2014;32:415-25. 
doi:10.1016/j.det.2014.03.009.

[13] Plaetzer K, Krammer B, Berlanda J, Berr F, Kiesslich T. Photophysics and photochemistry of photodynamic therapy: Fundamental aspects. Lasers Med Sci 2009;24:259-68. doi:10.1007/s10103-008-0539-1.

[14] Macdonald I, Dougherty T. Basic principles of photodynamic therapy. J Porphyrins 2001:10529.

[15] Ogilby PR. Singlet oxygen: there is indeed something new under the sun. Chem Soc Rev 2010;39:3181. doi:10.1039/b926014p.

[16] Ormond AB, Freeman HS. Dye sensitizers for photodynamic therapy. Materials (Basel) 2013;6:817-40. doi:10.3390/ma6030817.

[17] Baldassarre F, Foglietta F, Vergaro V, Barbero N, Capodilupo AL, Serpe L, et al. Photodynamic activity of thiophene-derived lysosome-specific dyes. J Photochem Photobiol B Biol 2016;158:16-22. doi:10.1016/j.jphotobiol.2016.02.013.

[18] Dichiara M, Prezzavento O, Marrazzo A, Pittalà V, Salerno L, Rescifina A, et al. Recent advances in drug discovery of phototherapeutic non-porphyrinic anticancer agents. Eur J Med Chem 2017. doi:10.1016/j.ejmech.2017.08.070.

[19] Atchison J, Kamila S, Nesbitt H, Logan KA, Nicholas DM, Fowley C, et al. Iodinated cyanine dyes: a new class of sensitisers for use in NIR activated photodynamic therapy (PDT). Chem Commun 2017;53:2009-12. doi:10.1039/C6CC09624G.

[20] Serpe L, Ellena S, Barbero N, Foglietta F, Prandini F, Gallo MP, et al. Squaraines bearing halogenated moieties as anticancer photosensitizers: Synthesis, characterization and biological evaluation. Eur J Med Chem 2016;113:187-97. doi:10.1016/j.ejmech.2016.02.035.

[21] Yang X, Shi C, Tong R, Qian W, Zhau HE, Wang R, et al. Near IR heptamethine cyanine dyemediated cancer imaging. Clin Cancer Res 2010;16:2833-44. doi:10.1158/1078-0432.CCR10-0059.

[22] Wang Y, Liu T, Zhang E, Luo S, Tan X, Shi C. Preferential accumulation of the near infrared heptamethine dye IR-780 in the mitochondria of drug-resistant lung cancer cells. Biomaterials 2014;35:4116-24. doi:10.1016/j.biomaterials.2014.01.061.

[23] Onoe S, Temma T, Shimizu Y, Ono M, Saji H. Investigation of cyanine dyes for in vivo optical imaging of altered mitochondrial membrane potential in tumors. Cancer Med 2014;3:775-86. doi:10.1002/cam4.252. 
[24] Pisoni DS, Ce A, Borges A, Petzhold CL, Rodembusch FS, Campo LF. Symmetrical and Asymmetrical Cyanine Dyes. Synthesis, Spectral Properties, and BSA Association Study 2014.

[25] Winstead AJ, Nyambura G, Matthews R, Toney D, Oyaghire S. Synthesis of quaternary heterocyclic salts. Molecules 2013;18:14306-19. doi:10.3390/molecules181114306.

[26] Barbero N, Magistris C, Park J, Saccone D, Quagliotto P, Buscaino R, et al. Microwaveassisted synthesis of near-infrared fluorescent indole-based squaraines. Org Lett 2015;17:3306-3309.

[27] Park J, Barbero N, Yoon J, Dell'Orto E, Galliano S, Borrelli R, et al. Panchromatic symmetrical squaraines: a step forward in the molecular engineering of low cost blue-greenish sensitizers for dye-sensitized solar cells. Phys Chem Chem Phys 2014;16:24173-7. doi:10.1039/C4CP04345F.

[28] Owens EA, Bruschi N, Tawney JG, Henary M. A microwave-assisted and environmentally benign approach to the synthesis of near-infrared fluorescent pentamethine cyanine dyes. Dye Pigment 2015;113:27-37. doi:10.1016/j.dyepig.2014.07.035.

[29] Bertolino CA, Ferrari AM, Barolo C, Viscardi G, Caputo G, Coluccia S. Solvent effect on indocyanine dyes: A computational approach. Chem Phys 2006;330:52-9. doi:10.1016/j.chemphys.2006.07.045. 